\title{
Height of attachment on seagrass leads to trade-off between growth and survival in the bay scallop Argopecten irradians
}

\author{
William G. Ambrose, $\mathrm{Jr}^{1}$, Elizabeth A. Irlandi ${ }^{2}$ \\ ${ }^{1}$ Department of Biology, East Carolina University, Greenville, North Carolina 27858, USA \\ ${ }^{2}$ University of North Carolina at Chapel Hill, Institute of Marine Sciences, Morehead City, North Carolina 28557, USA
}

\begin{abstract}
Recent experiments have demonstrated that the canopy of seagrass beds provides a refuge from predation for juvenile bay scallops. Argopecten irradians. Elevation off the bottom may also place juvenile scallops attached to grass blades in flow regimes more favorable to growth than if they settled on the bottom. Juvenile scallops (mean shell height $12.3 \mathrm{~mm}$ ) were attached to seagrass mimics at 0,5 , and $15 \mathrm{~cm}$ off the bottom and their survival was followed over three $24 \mathrm{~h}$ periods; growth and survival were then monitored after 2,3 , and $9 \mathrm{wk}$. Survival at the $0 \mathrm{~cm}$ elevation was significantly lower than at $15 \mathrm{~cm}$ while survival at the $5 \mathrm{~cm}$ elevation was not significantly different from either extreme. Scallops grew fastest at $0 \mathrm{~cm}$, significantly slower at $15 \mathrm{~cm}$, and slowest at $5 \mathrm{~cm}$. Selection of attachment locations of the bottom by juvenile scallops incurs the cost of reduced growth and scallops are faced with a trade-off between reducing their risk of predation and maximizing their growth.
\end{abstract}

\section{INTRODUCTION}

Organisms are expected to evolve characteristics which reduce their susceptibility to predation if predation is a historically significant source of mortality (Vermeij 1982). Behaviors which reduce predation are common (see review by Lima \& Dill 1990), but are often accompanied by increased energetic costs leaving prey with a trade-off between reducing their risk of predation and maximizing their intake and use of energy (Werner 1991). Freshwater and terrestrial organisms often select habitats on the basis of predation risk (Lima \& Dill 1990). Examples of such habitat selection exist for marine systems (Leber 1985, Warren 1985, Main 1987, Holbrook \& Schmitt 1988, Pohle et al. 1991, Posey \& Hines 1991), but only one of these studies (Holbrook \& Schmitt 1988) examines the trade-off between avoiding predation and maximizing food intake.

Predation is an important structuring force in seagrass beds (see review by Orth et al. 1984) and prey might, therefore, be expected to have modified their behavior in response to predators. The association between bay scallops Argopecten irradians and sea- grass beds has long been recognized (Belding 1910) and it is generally accepted that juveniles attach themselves with byssal threads on seagrass blades above the bottom to avoid predation by epibenthic predators and/or the effects of siltation (Thayer \& Stuart 1974 , Castagna 1975). The value of the seagrass canopy as a refuge for juvenile bay scallops from predation has recently been confirmed by Pohle et al. (1991).

This recent experimental work demonstrating increased survivorship of juvenile scallops with increased distance off the bottom was done in a region where the blades of the dominant seagrass (Zostera marina) range from 24 to $50 \mathrm{~cm}$ in length (Eckman 1987, Pohle et al. 1991). In other parts of the bay scallop's range, the seagrass canopy is often much shorter. The mean blade lengths of $Z$. marina and the other dominant seagrass in North Carolina, Halodule wrightii, range from 15 to $25 \mathrm{~cm}$ in length (Irlandi \& Peterson 1991, Irlandi unpubl.), and while juvenile scallops can be found attached throughout the canopy, they typically attach 3 to $7 \mathrm{~cm}$ off the bottom (Eckman et al. 1989, Ambrose \& Rivera unpubl.). Shorter seagrass canopies may not offer juvenile scallops the same protection from predation as taller canopies. 
In addition to affecting survival, the height off the bottom at which juvenile scallops attach may also affect their growth. Seagrass beds modify water flow (Fonseca et al. 1982, Peterson et al. 1984, Gambi et al. 1990, Irlandi \& Peterson 1991) and within seagrass beds, current velocities increase with increasing distance off the bottom (Eckman et al. 1989). Water flow is known to have a large effect on the feeding activity and growth of suspension feeders such as bay scallops (Kirby-Smith 1972, Walne 1972, Wildish 1977, Wildish \& Kristmanson 1979, 1985, Eckman et al. 1989, Fréchette et al. 1989) and juvenile scallops are known to change their orientation relative to water flow, presumably to maximize their feeding efficiency (Eckman et al. 1989). It is possible, therefore, that not all positions on seagrass blades are equally favorable for scallop growth and, consequently, there may be a conflict between the best elevation above the bottom for grow th and the best elevation for avoiding predators.

Here, we report on a study designed to examine the effect of attachment height on both the growth and survival of the bay scallop in North Carolina (USA) where the seagrass canopy typically does not exceed $25 \mathrm{~cm}$ in height. We initially hypothesized that the usual attachment height in this region of only a few centimeters above the bottom would provide little protection from predators compared to attachment on the bottom, but that growth might be affected.

\section{METHODS}

Study site. Attachment height of scallops was manipulated in the field at Oscar Shoal which is located on the east side of Middle Marsh in Back Sound, North Carolina (see Irlandi \& Peterson 1991 for a map of this area). The tidal range in this region is about $1 \mathrm{~m}$ and at low tide during our study the site was covered with 10 to $20 \mathrm{~cm}$ of water. Seagrass beds on Oscar Shoal range in area from a few $\mathrm{m}^{2}$ to tens of $\mathrm{m}^{2}$ and contain a seasonally changing mixture of Halodule wrightii and Zostera marina. In order to characterize the abundance and biomass of seagrass and the height of the seagrass canopy, 10 replicate cores $\left(77 \mathrm{~cm}^{2}\right.$ by $15 \mathrm{~cm}$ deep) were taken at the conclusion of the experiment from the center of the beds where the experiment was conducted. Seagrass shoots in each core were separated by species, counted, and the longest blade length in each shoot measured. The dry weight (dried at $60^{\circ} \mathrm{C}$ to constant weight) of the above-ground shoots was then determined

Manipulation of attachment height. To assess the effect of vertical attachment height on growth and survivorship of juvenile scallops, we tethered scallops to artificial seagrass mimics at 3 elevations above the seafloor. Mimics were constructed by attaching one end of a $40 \mathrm{~cm}$ long by $0.5 \mathrm{~cm}$ wide piece of green polypropylene ribbon (Synthetic Fibers Inc., Newton, PA, USA) to a $15 \mathrm{~cm}$ long wire staple and the other end to a small float [buoyancy $3.3 \mathrm{oz}$ (ca $93.6 \mathrm{~g}$ ); Memphis Net and Twine Co. Inc., Memphis, TN, USA]. The staples anchored the mimics to the seafloor while the buoys held the ribbon up in the water column. The mimics faithfully imitate the movement and position of natural seagrass blades in response to water movement and changes in water column height. Buoys were numbered to allow individual identification of scallops. In order to provide a suitable attachment surface for gluing scallops to mimics, a small tab $(0.5 \times 0.5 \mathrm{~cm})$ of vinyl surveyor's tape was affixed with hot glue to each mimic at 0,5 , or $15 \mathrm{~cm}$ above the staple. A drop of Quick Gel Super Glue was applied to the vinyl tab and a towel-dried scallop was placed left valve down with the hinge facing towards the float (natural attachment orientation). Scallops attached in this manner are extremely difficult to remove and even considerable handling and disturbance during transport failed to dislodge a single individual. Scallops (mean shell length $12.3 \mathrm{~mm}, \mathrm{n}=300, \mathrm{SE}=0.06$; measured to the nearest $0.1 \mathrm{~mm}$ ) were individually attached to a mimic at each of the elevations $(0,5$, and $15 \mathrm{~cm}$ from the bottom). Each elevation received 100 scallops. The mimics with attached scallops were placed haphazardly in the seagrass beds of Oscar Shoal on 19 November 1991 by inserting the wire staples into the sediment.

To control for potential mortality from handling, tethered scallops were placed in predator-exclusion cages. Cages were constructed from 6-mm unoriented vexar mesh attached with cable ties to a $0.25 \mathrm{~m}^{2} \times$ $0.30 \mathrm{~m}$ tall cubic pvc frame. Two iron poles, $70 \mathrm{~cm}$ in length $\times 1.4 \mathrm{~cm}$ in diameter, were attached to opposite corners of the cages. The poles were pushed into the sediment to anchor the cages. There were 3 cages. Each cage received 15 scallops, 5 individuals tethered on separate seagrass mimics at each of the 3 heights. Scallops were placed in the cages and censused on the same schedule as the uncaged scallops. No scallops from the cages were ever found dead or missing (unglued), confirming that handling had no effect on survivorship and that the technique of attaching the scallops to the seagrass mimics was effective. Therefore, non-caged scallops with 2 entire valves still glued to the mimic, but with the meat of the animal missing, and entire scallops missing from tethers were considered to have been consumed by predators.

Tethered scallops were checked every $24 \mathrm{~h}$ for the first $3 \mathrm{~d}$ of the experiment to obtain $24 \mathrm{~h}$ survivorship rates. A distinction was made during censusing between dead (meat missing but at least part of shell 
remaining) and missing individuals. During the first 2 days, all dead and missing scallops were replaced so that there were 100 scallops for each elevation on all 3 days. On the third day, scallops were checked, but dead and missing individuals were not replaced. The percentage of scallops recovered live from each elevation for each of the $24 \mathrm{~h}$ periods was compared using a 1-way fixed factor ANOVA. Prior to analysis, percentages were arcsin transformed. A Student-NewmanKeuls (SNK) test was used for post-hoc comparisons of percent survival among elevations.

The effect of elevation on scallop growth was assessed approximately 2,3 , and $9 \mathrm{wk}$ after the end of the $24 \mathrm{~h}$ censuses. At each of these times, the shell height of surviving scallops was measured to the nearest $0.1 \mathrm{~mm}$. The effect of elevation on growth was determined with a 1-way ANCOVA in which the amount of growth was used as the dependent variable, initial size as the covariate, and elevation above the bottom as the independent variable. Homogeneity of slopes for all times was confirmed prior to ANCOVA as no interaction was detected between the independent variable, attachment height, and the covariate $(2 \mathrm{wk}$ $F=1.09, \mathrm{df}=2, \mathrm{p}=0.3367 ; 3 \mathrm{wk} F=1.83, \mathrm{df}=2$, $\mathrm{p}=0.1638 ; 9$ wk $F=0.52, \mathrm{df}=2, \mathrm{p}=0.5977$ ). BryantPaulson tests were used to compare growth of scallops among different elevations for each time period (Huitema 1980).

Survivorship was also monitored at 2, 3, and $9 \mathrm{wk}$ and differences among elevations were compared using separate $G$-tests with the significance levels adjusted to maintain an experimentwise level of $\alpha<0.05$ (Snedecor \& Cochran 1980). Loss of scallops due to factors other than predation would bias our interpretation of the survivorship data if loss varied with elevation. Over $9 \mathrm{wk}$, contact between scallops attached at the base of the seagrass mimics and the sediment surface might dislodge these individuals while currents and waves might remove scallops attached higher on the blade more often than those nearer the bottom. Consequently, we also compared survivorship among elevations using only dead scallops as evidence of predation. Since size-selective predation may influence our interpretation of the growth and survivorship data, we compared the survivorship after $9 \mathrm{wk}$ of scallops in 3 size classes (small $=12.3$ to $15.3 \mathrm{~cm}$, medium $=15.4$ to $18.2 \mathrm{~cm}$, large $=18.3$ to $21.1 \mathrm{~cm}$ ) at each elevation using a $G$-test of independence.

\section{RESULTS}

Halodule wrightii is the dominant seagrass species in North Carolina in the autumn, and $76.1 \%$ of the seagrass shoots in the beds where we tethered scallops was $H$. wrightii while the remaining was Zostera marina. The combined average shoot density of these 2 species was 27.6 shoots per $77 \mathrm{~cm}^{2}$ core (standard error $=2.9, \mathrm{n}=10$; equivalent to 3584 shoots $\mathrm{m}^{-2}$ ) and the average dry weight was $0.92 \mathrm{~g}$ core ${ }^{-1}$ $\left(\mathrm{SE}=0.12, \mathrm{n}=10\right.$; equivalent to $\left.119 \mathrm{~g} \mathrm{~m}^{-2}\right)$. The average length of the tallest blade in each shoot in each core was first determined (range 7.4 to $14.8 \mathrm{~cm}$ ) and these averages were used to calculate the average tallest blade length per shoot per core, which was $10.3 \mathrm{~cm}$ ( $\mathrm{SE}=0.7, \mathrm{n}=10$ ).

Survival of tethered scallops over a $24 \mathrm{~h}$ period varied significantly as a function of elevation (Fig. 1). SNK tests indicated that survival was significantly lower at $0 \mathrm{~cm}$ compared to $15 \mathrm{~cm}$ above the bottom with the $5 \mathrm{~cm}$ elevation not significantly different from either extreme. Over 9 wk there was a trend of increased survivorship with greater elevation (Table 1). Observed frequencies of recovery were independent of elevation after 2 and $3 w k\left(\chi_{0.05 .2}^{2}=5.99 ; G=2.46\right.$ and 3.78 respectively). After $9 \mathrm{wk}$, however, there was a significant effect of elevation on survival, with survival greater at $15 \mathrm{~cm}$ than at $0 \mathrm{~cm}$ and intermediate at $5 \mathrm{~cm}$ (Table 1$)\left(\chi^{2} \text { (adjusted }\right)_{0.05(3,2)}=8.15_{i}$ $0 \mathrm{~cm}$ vs $5 \mathrm{~cm}: G=3.02 ; 0 \mathrm{~cm}$ vs $15 \mathrm{~cm}: G=12.36$; $5 \mathrm{~cm}$ vs $15 \mathrm{~cm}: G=3.14$ ). Scallop survivorship after $9 \mathrm{wk}$ was independent of scallop size at $3 \mathrm{wk}$ for all 3 elevations on seagrass mimics $\left(\chi_{0.05 .2}^{2}=5.99 ; 0 \mathrm{~cm}\right.$ : $G=2.98 ; 5 \mathrm{~cm}: G=1.8 ; 15 \mathrm{~cm}: G=1.1)$.

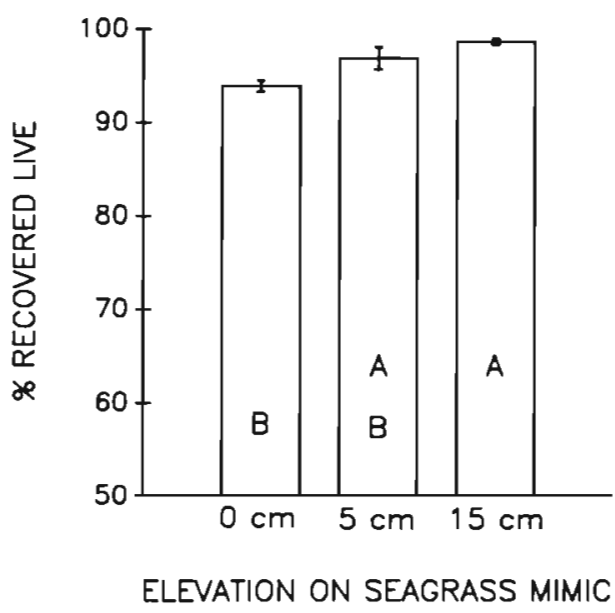

Fig. 1. Argopecten irradians. Mean percent of juvenile scallops recovered live per $24 \mathrm{~h}(\mathrm{n}=3)$ from each of the 3 elevations on seagrass mimics. Error bars represent 1 standard error. A 1-way, model I ANOVA compared the proportion of scallops surviving (arcsine transformed) for $24 \mathrm{~h}$ among the 3 elevations $(F=7.68, \mathrm{df}=2,6, p<0.02)$. Bars with the same letter indicate that the means they represent are not significantly different from each other $(p>0.05$, Student-Newman-Keuls test) 
Table 1. Argopecten irradians. Percent of scallops surviving at each of 3 elevations $(0,5$ and $15 \mathrm{~cm})$ on seagrass mimics after 2, 3 and 9 wk. Means connected by common underline are not significantly different at $p>0.05$ (G-test of independence)

\begin{tabular}{|cccc|}
\hline Time & $0 \mathrm{~cm}$ & $\begin{array}{c}\text { Elevation } \\
5 \mathrm{~cm}\end{array}$ & $15 \mathrm{~cm}$ \\
\hline $2 \mathrm{wk}$ & 76.0 & 84.5 & 82.3 \\
$3 \mathrm{wk}$ & $\underline{63.0}$ & 71.1 & 77.1 \\
$9 \mathrm{wk}$ & $\underline{39.0}$ & 49.5 & 61.4 \\
\hline
\end{tabular}

Table 2. Argopecten irradians. Percent of scallops dead (meat missing but part of shell remaining) and missing at each of the 3 elevations $(0,5$ and $15 \mathrm{~cm})$ on seagrass mimics after 2,3 and $9 \mathrm{wk}$. Percent of scallops dead, missing, and live (Table 1) do not always total 100 because some individuals were never relocated

\begin{tabular}{|lrr|}
\hline Elevation & Dead & Missing \\
\hline $2 \mathrm{wk}$ & & \\
$0 \mathrm{~cm}$ & 13.0 & 11.0 \\
$5 \mathrm{~cm}$ & 10.3 & 5.2 \\
$15 \mathrm{~cm}$ & 9.4 & 8.3 \\
$3 \mathrm{wk}$ & & \\
$0 \mathrm{~cm}$ & 19.0 & 17.0 \\
$5 \mathrm{~cm}$ & 10.3 & 18.6 \\
$15 \mathrm{~cm}$ & 11.4 & 12.5 \\
$9 \mathrm{wk}$ & & \\
$0 \mathrm{~cm}$ & 25.0 & 32.0 \\
$5 \mathrm{~cm}$ & 15.5 & 27.8 \\
$15 \mathrm{~cm}$ & 12.5 & 18.7 \\
\hline
\end{tabular}

The proportions of scallops recorded as dead and those missing were similar for the $9 \mathrm{wk}$ experiment (Table 2). A slightly greater proportion of scallops were dead than missing at 2 wk and between 6 and $12 \%$ more were missing than dead at $9 \mathrm{wk}$. If the survival data is analyzed using only dead scallops as evidence of predation, the same pattern of increased scallop survival with greater elevation which was evident when both dead and missing scallops were considered evidence of predation exists. Survivorship was again independent of elevation on the blades after 2 and 3 wk $\left(x_{0}^{2} 05,2=5.99 ; G=0.94\right.$ and 4.1 respectively) and after $9 \mathrm{wk}$ there was a significant effect of elevation on survival with survival greater at $15 \mathrm{~cm}$ than at $0 \mathrm{~cm}$ and intermediate at $5 \mathrm{~cm}$ $\left(x^{2} \text { (adjusted }\right)_{0.05(3.2)}=8.15 ; 0 \mathrm{~cm}$ vs $5 \mathrm{~cm}: G=3.04$; $0 \mathrm{~cm}$ vs $15 \mathrm{~cm}: G=8.40 ; 5 \mathrm{~cm}$ vs $15 \mathrm{~cm}: G=0.98)$.

Growth of scallops also varied significantly with height of attachment (Fig. 2). Post-hoc comparisons after 2 and $3 \mathrm{wk}$ of growth indicate significantly faster
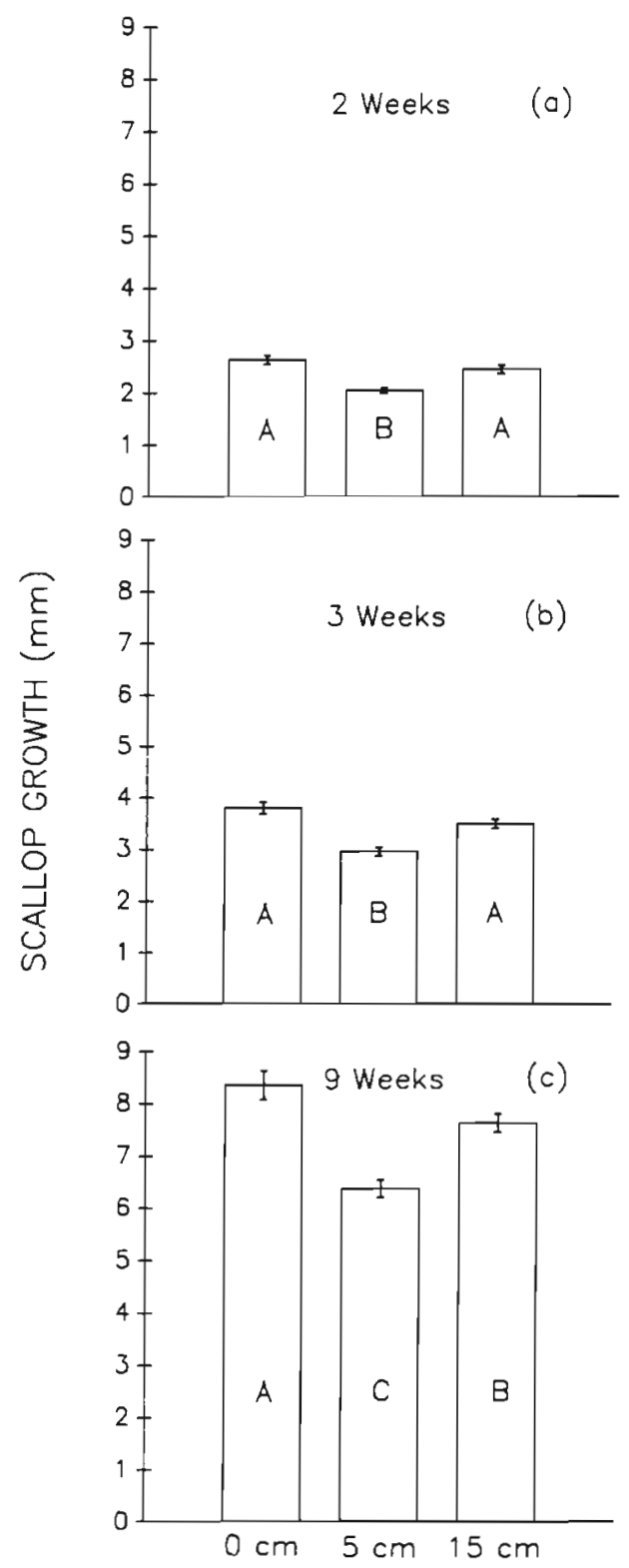

\section{ELEVATION ON SEAGRASS MIMIC}

Fig. 2. Argopecten irradians. Mean growth of juvenile scallops at 3 elevations on seagrass mimics after: (a) 2 wk, (b) 3 wk, and (c) 9 wk. Error bars represent 1 standard error. Bars with the same letter indicate that the means they represent are not significantly different from each other ( $p>0.05$, Bryant-Paulson test). The ANCOVA comparing the final size (shell height) of juvenile scallops among the 3 elevations for each time period indicated that initial size was never significant $(p \gg 0.05)$ and height was always highly significant $(p<0.0001)$

growth rates for scallops at $0 \mathrm{~cm}$ and $15 \mathrm{~cm}$ than at the $5 \mathrm{~cm}$ elevation (Fig. 2a, b). By 9 wk, scallop growth was significantly different among all elevations with the greatest growth at $0 \mathrm{~cm}$, followed by $15 \mathrm{~cm}$, and the least at $5 \mathrm{~cm}$ (Fig. 2c). 


\section{DISCUSSION}

The differences in survivorship among elevations that we observed agree with the results of Pohle et al. (1991) and indicate that the seagrass canopy provides a refuge from predation for juvenile scallops. Though statistically significant, differences in survival among elevations were small and perhaps not biologically meaningful when compared over $24 \mathrm{~h}$ (Fig. 1), but the same pattern with larger differences in survival among elevations was observed after 9 wk (Table 1). Our results indicate that scallops need attach only $15 \mathrm{~cm}$ or less off the bottom, compared with the 20 to $35 \mathrm{~cm}$ of Pohle et al. (1991), to gain some protection from epibenthic predators. Laboratory observations confirm that blue crabs Callinectes sapidus and stone crabs Menippe mercenaria, both common predators in the seagrass beds of North Carolina, prey on juvenile scallops of the size we tethered and are able to and often do remove the entire animal from the seagrass mimic We have also observed whelks Busycon canaliculatum and $B$. contrarium feeding on juvenile scallops in the field, and whelks are very common in the seagrass beds of Oscar Shoal (pers. obs.). Whelks remove the meat from tethered scallops and leave behind a virtually undamaged shell (pers. obs.). A host of fishes are reported to prey on juvenile scallops (Adams 1974). Field and laboratory observations confirm that 2 species of fish common to seagrass beds in our region, toadfish Opsaus tau and sheepshead Archosargus probatocephalus, feed on tethered scallops and usually remove the entire animal. Most of these species would seem capable of reaching scallops attached only $5 \mathrm{~cm}$ off the bottom, but in the case of some of the invertebrate predators perhaps not $15 \mathrm{~cm}$. More field and laboratory observations on the behavior of scallop predators are needed before the mechanism of how the seagrass canopy functions as a refuge from predators for juvenile scallops will be fully understood.

Many of the likely predators on scallops remove the scallop from the seagrass mimic, so missing individuals (Table 2) were probably preyed upon. Nevertheless, survival still increases with greater elevation when only individuals with a portion of the shell remaining on the blade are considered as evidence of predation. This indicates that while some scallops may have fallen off the seagrass mimics over the $9 \mathrm{wk}$ of the experiment, these lost individuals did not affect the interpretation of our results.

While juvenile scallops clearly reduce their chances of being preyed upon by attaching on grass blades above the bottom, there may be other adaptive reasons for the association between seagrass and juvenile scallops (Pohle et al. 1991). It has been suggested that elevation off the bottom allows juvenile scallops to avoid sediment deposition and may also place them in flow regimes more favorable for growth than if they settled on the bottom (Belding 1910, Duggan 1973 , Eckman et al. 1989). Growth of many suspension feeders is typically faster in areas of higher current flow due to increased food supply through horizontal advection and turbulent mixing (Wildish \& Krismanson 1985, Fréchette et al. 1989). Our results of fastest growth on the bottom contradict the prediction of increased growth higher in the seagrass canopy due to faster currents. The effects of increased water flow on scallop growth have been variable and suggest that growth of scallops may be inhibited at higher flows (Kirby-Smith 1972, Wildish et al. 1987, Cahalan et al. 1989, Eckman et al. 1989). Oscar Shoal is exposed to wind waves from 3 directions and has grass densities and grass blade and bed morphology typical of exposed sites (Fonseca et al. 1983). Current velocities above the bottom may often be high enough to inhibit scallop growth at this site. The fact that growth was lowest at the intermediate elevation $(5 \mathrm{~cm})$ suggests that growth of juvenile scallops is complex and needs to be examined further in field and laboratory experiments over a range of energy regimes and particle types (organic versus inorganic).

Size-selective predation could interfere with our interpretation of both the survivorship and growth data. If larger scallops in the size range we manipulated are more likely to be preyed upon, then the faster growth of scallops near the bottom would make them more susceptible to predators, reducing their survivorship and providing the illusion that survivorship varied with attachment height over the 9 wk experiment. Tettelbach (1986), however, working with the northern bay scallop Argopecten irradians irradians, demonstrated that predation on scallops by 9 species of crabs decreased with increasing scallop size up to a size of approximately $40 \mathrm{~mm}$ (shell height) when scallops reached a partial size refuge. We used scallops less than $40 \mathrm{~mm}$. On the other hand, selective removal of small scallops from the $0 \mathrm{~cm}$ elevation would make it appear that growth was highest at $0 \mathrm{~cm}$ because only large individuals would survive to be measured. There was no relationship, however, between scallop size at $3 \mathrm{wk}$ and survival at $9 \mathrm{wk}$ for any of the elevations. Even after $9 \mathrm{wk}$, scallops attached at $5 \mathrm{~cm}$ grew only about $3.0 \mathrm{~mm}$ less than individuals at $0 \mathrm{~cm}$. Such a small difference is not likely to affect the feeding behavior of most predators. Size-selective predation probably did not confound our interpretation of survival or growth data.

Our results suggest that juvenile scallops are at least sometimes faced with a trade-off between growth and survival when selecting attachment locations on seagrass blades because the elevation at which growth 
was the highest $(0 \mathrm{~cm})$ was also the elevation with the lowest survivorship. While the trade-off between a much higher risk of predation and slightly slower growth would seem to be an easy one to reconcile, it should be remembered that slower growth increases the risk of predation because it prolongs the time before individuals reach the partial size refuge from crab predation observed by Tettelbach (1986). It is difficult to reconcile these results with the observed average scallop attachment height of between $3.5 \mathrm{~cm}$ $(n=43, S E=0.3 ;$ Eckman et al. 1989) and $6.6 \mathrm{~cm}$ ( $\mathrm{n}=100, \mathrm{SE}=0.4$; Ambrose \& Rivera unpubl.) recorded in nearby grass beds. These 2 average attachment heights, however, are significantly different from each other ( $t=4.859, \mathrm{p}<0.001)$, suggesting that scallops may vary their height of attachment under different conditions. The byssal attachment of juvenile scallops is dynamic and individuals commonly detach, crawl around using their foot, and reattach (Belding 1910, Eckman 1987, Pohle et al. 1991). Individuals may change their attachment position in response to changes in water flow and the abundance of predators. Further work may demonstrate that juvenile scallops display some of the flexibility in microhabitat selection exhibited by other organisms faced with similar tradeoffs between risk of predation and maximizing food intake (Wellborn \& Robinson 1987, Holbrook \& Schmitt 1988, Lima \& Dill 1990).

Acknowledgements. We thank B. Orlando for field and laboratory assistance and F. Micheli, B. Orlando, C. Peterson, G. Skilleter, R. Warwick, and an anonymous reviewer for comments on the manuscript. The ribbon used to construct seagrass mimics was kindly donated by Synthetic Fibers Inc., Newton, PA, USA. This work was funded by a grant from the National Oceanographic and Atmospheric Administration, Coastal Ocean Program NCSU-Sea Grant \#46326. The views expressed herein are those of the authors and do not necessarily reflect the views of NOAA or any of its sub-agencies. W.G.A. also thanks the University of North Carolina at Chapel Hill Institute of Marine Sciences for laboratory and office space.

\section{LITERATURE CITED}

Adams, S. M. (1974). Structural and functional analysis of eelgrass fish communities. Ph.D. thesis, University of North Carolina at Chapel Hill

Belding, D. L. (1910). A report upon the scallop fishery of Massachusetts. The Commonwealth of Massachusetts, Boston

Cahalan, J. A., Siddall, S. E., Luckenbach, M. W. (1989). The effects of flow velocity, food concentration, and particle fluxes on the growth rates of juvenile bay scallops, Argopecten irradians. J exp. mar. Biol. Ecol. 129: 45-60

Castagna. M. (1975). Culture of the bay scallop, Argopecten irradians, in Virginia. Mar. Fish. Rev. 37: 19-24

Duggan, W. P. (1973). Growth and survival of bay scallop.
Argopecten irradians at various locations in the water column and at various densities. Proc. natl Shellfish. Ass 63: $68-71$

Eckman, J E. (1987). The role of hydrodynamics in recruitment, growth, and survival of Argopecten irradians (L.) and Anomia simplex (D'Orbigny) within eelgrass meadows. J. exp. mar. Biol. Ecol. 106: 165-191

Eckman, J. E., Peterson, C. H., Cahalan, J. A. (1989). Effects of flow speed, turbulence, and orientation on growth of juvenile bay scallops Argopecten irradians concentricus (Say). J. exp. mar. Biol. Ecol. 132: 123-140

Fréchette, M., Butman, C. A., Geyer, W. R. (1989). The importance of boundary-layer flow in supplying phytoplankton to the benthic suspension feeder, Mytilus edulis L. Limnol. Oceanogr. 34: 19-36

Fonseca, M. S., Fisher, J. S., Zieman, J. C., Thayer, G. W (1982). Influence of seagrass Zostera marina L., on current flow. Estuar. coast. Shelf Sci. 14: 351-364

Fonseca, M. S., Zieman, J. C., Thayer, G. W., Fisher, J. S. (1983). The role of current velocity in structuring eelgrass (Zostera marina) meadows. Estuar. coast. Shelf Sci. 17 $367-380$

Gambi, M. C., Nowell, A. R. M., Jumars, P. A. (1990). Flume observations on flow dynamics in Zostera marina leelgrass) beds. Mar. Ecol. Prog. Ser. 61: 159-169

Holbrook, S. A., Schmitt, R. J. (1988). The combined effects of predation risk and food reward on patch selection Ecology 69: 125-134

Huitema, B. E. (1980). The analysis of covariance and alternatives. John Wiley and Sons, New York

Irlandi, E. A., Peterson, C. H. (1991). Modification of animal habitat by large plants: mechanisms by which seagrasses influence clam growth. Oecologia 87: 307-318

Kirby-Smith, W. W. (1972). Growth of the bay scallop: the influence of experimental water currents. J. exp. mar. Biol. Ecol. 8: 7-18

Leber, K. M. (1985). The influence of predatory decapods, refuge, and microhabitat selection in seagrass communities. Ecology 66: 1951-1964

Lima, S. L., Dill, L. M. (1990). Behavioral decisions made under the risk of predation: a review and prospectus. Can. J. Zool. 68: 619-640

Main, K. L. (1987). Predator avoidance in seagrass meadows: prey behavior, microhabitat selection, and cryptic coloration. Ecology 68: 170-180

Orth, R. J., Heck, K. L. Jr, van Montfrans, J. (1984). Faunal communities in seagrass beds: a review of the influence of plant structure and prey characteristics on predatory-prey relationships. Estuaries $7(4 \mathrm{~A}): 339-350$

Peterson, C. H., Summerson, H. C., Duncan, P. B. (1984). The influence of seagrass cover on population structure and individual growth rate of a suspension-feeding bivalve, Mercenaria mercenaria. J. mar. Res. 42: 123-138

Pohle, D. G., Bricelj, V. M., Garcia-Esquivel, Z. (1991). The eelgrass canopy: an above-bottom refuge from benthic predators for juvenile bay scallops Argopecten irradians. Mar. Ecol. Prog. Ser. 74: 47-59

Posey, M. H., Hines, A. H. (1991). Complex predator-prey interactions within an estuarine benthic community. Ecology 72: 2155-2169

Snedecor, G. W., Cochran, W. G. (1980). Statistical methods, 7 th edn. Iowa State University Press, Ames

Tettelbach. S. T (1986). Dynamics of crustacean predation on the northern bay scallop. Argopecten irradians irradians. Ph.D. thesis, University of Connecticut, Storrs

Thayer, G. W., Stewart, H. H. (1974). The bay scallop makes its bed of seagrass. Mar. Fish. Rev. 36: 27-30 
Vermeij, G. J. (1982). Unsuccessful predation and evolution. Am. Nat. 120: 701-720

Walne, P. R. (1972). The influence of current speed, body size, and water temperature on the filtration rate of five species of bivalves. J. mar. biol. Ass. U.K. 52: 345-374

Warren, J. H. (1985). Climbing as an avoidance behavior in the saltmarsh periwinkle, Littorina irrorata (Say). J. exp. mar. Biol. Ecol. 89: 11-28

Wellborn, G. A., Robinson, J. V. (1987). Microhabitat selection as an antipredator strategy in the aquatic insect Pachydiplax longipennis Burmeister (Odonata: Libellulidae). Oecologia 71: 185-189

Werner, E. E. (1991). Nonlethal effects of a predator on competitive interactions between two anuran larvae. Ecology

This article was presented by J. Gray, Oslo, Norway
72: $1709-1720$

Wildish, D. J. (1977). Factors controlling marine and estuarine sublittoral macrofauna. Helgoländer wiss. Meersunters. 30: 445-454

Wildish, D. J., Kristmanson, D. D. (1979). Tidal energy and subtidal macrobenthic animals in estuaries. J. Fish. Res. Bd Can. 36: 1197-1206

Wildish, D. J., Kristmanson, D. D. (1985). Control of suspension feeding bivalve production by current speed. Helgoländer wiss. Meeresunters. 39: 237-243

Wildish, D. J., Kristmanson, D. D., Hoar, R. L., DeCoste, A. M., McCormick, S. D., White, A. W. (1987). Giant scallop feeding and growth responses to flow. J. exp. mar. Biol. Ecol. 113: 207-220

Manuscript first received: July 1, 1992

Revised version accepted: October 28, 1992 